\title{
Regulation by protein kinase of phagocytosis of Mycobacterium leprae by macrophages
}

\author{
K. PRABHAKARAN, E. B. HARRIS and B. RANDHAWA \\ US Public Health Service, GWL Hansen's Disease Center@ Louisiana State University, PO Box 25072, Baton \\ Rouge, LA 70894-5072, USA
}

\begin{abstract}
Mycobacterium leprae multiplies within host macrophages. The mechanism of internalisation of the bacteria by the phagocytic cells is unknown. In this study, $M$. leprae was purified from the foot pads of experimentally infected $n u / n u$ mice. Peritoneal macrophages were harvested from BALB/c mice or $\mathrm{C57}$ beige $(\mathrm{bg} / \mathrm{bg}) \mathrm{mice}$. The effect of protein kinase inhibitors (erbstatin, genistein or staurosporine for $B A L B / c$ and $b g / b g$ mice, plus herbimycin for $b g / b g$ mice) on phagocytosis of the mycobacteria by the macrophage monolayers was tested. The untreated (control) macrophages phagocytosed M. leprae. Phagocytosis by BALB/c macrophages was inhibited by erbstatin and staurosporine but not by genistein; all the protein kinase inhibitors prevented uptake of $M$. leprae by $\mathrm{bg} / \mathrm{bg}$ cells. The results demonstrate that protein kinase regulates phagocytosis of $M$. leprae by macrophages. The mechanism might prove to be a rational drug target for mycobacteria that multiply intracellularly.
\end{abstract}

\section{Introduction}

Protein phosphorylase (EC 2.7.1.27) regulates a multitude of cell functions such as cell proliferation and differentiation, signal transduction, transcription and synaptic transmission. Phosphorylation involves the introduction of a phosphoryl group into a substrate through the formation of an ester bond between the compound and phosphoric acid. In the protein kinase superfamily there are two subdivisions: protein tyrosine kinases and protein serine/threonine kinases. The terminal phosphoryl group of ATP is transferred to specific tyrosine residues by one class of protein kinases and to serine/threonine residues by the other.

Protein tyrosine phosphorylation was first discovered in 1979 [1]. At one time it was believed that only eukaryotic cells possess protein kinases; now the activity has been detected in eubacteria and archaebacteria as well [2,3]. Protein kinase has been recognised as an evolutionarily conserved enzyme activity. Uncontrolled activation of tyrosine kinase is associated with many kinds of cancers and decrease in insulin receptor tyrosine kinase is associated with diabetes $[1,4]$.

Received 18 June 1999; revised version received 4 Aug. 1999; accepted 13 Sept. 1999.

Corresponding author: Dr K. Prabhakaran (e-mail: kprabhal (a)hotmail.com).
Pathogenic bacteria have adopted various strategies to invade their hosts. Many intracellular micro-organisms interact with host cell receptor molecules to induce their own internalisation; bacteria exploit eukaryotic protein kinases to enter mammalian cells. Protein kinase inhibitors prevent cell infection by blocking stimulation of receptor sites on the phagocytic cells of the host. Protein kinase is activated during phagocytosis [5]. Mycobacterium leprae phagocytosed by macrophages suppresses phagosome-lysosome fusion and the bacteria multiply within the cells. The present study examined the effect of kinase inhibitors on uptake of $M$. leprae by macrophages and the possible regulatory role of protein phosphorylase in phagocytosis.

\section{Materials and methods}

\section{Inhibitors}

Staurosporine, erbstatin, genistein and herbimycin were purchased from Calbiochem, La Jolla, CA, USA.

\section{Bacteria}

M. leprae was purified from the foot pads of experimentally infected $n u / n u \mathrm{BALB} / \mathrm{c}$ mice by homogenisation of the tissues and differential centrifugation of the homogenate. The bacterial pellet was washed thoroughly to remove host tissue elements. 


\section{Macrophages}

Peritoneal macrophages were harvested with heparinised Hanks's balanced salts solution from BALB/c (Simonsen Lab, Gilroy, CA, USA) or C57 beige $(b g / b g)$ mice (Jackson Laboratory, Bar Harbour, ME, USA). The cells were sedimented by centrifugation at $200 \mathrm{~g}$ for $10 \mathrm{~min}$ at $4^{\circ} \mathrm{C}$. The macrophages were suspended in a small volume of RPMI 1640 medium containing heated fetal bovine serum $15 \%, 20 \mathrm{~mm}$ HEPES (N-2-hydroxyethylpiperazine-N-2-ethane sulphonic acid), $\mathrm{NaHCO}_{3} 2 \mathrm{mg} / \mathrm{ml}, 2 \mathrm{mM}$ glutamine and gentamycin $50 \mu \mathrm{g} / \mathrm{ml}$. A cell count was made with acetic acid-methylene blue stain, and the number of cells in the medium was adjusted to $4 \times 10^{6} / \mathrm{ml}$ $(\mathrm{BALB} / \mathrm{c})$ or $2 \times 10^{6} / \mathrm{ml}(\mathrm{bg} / \mathrm{bg})$.

\section{Phagocytosis assay}

$B A L B / c$ macrophages. A round, 13-mm sterile coverslip (Thermanox Plastic, Nalge Nunc International, Napierville, IL, USA) was introduced into each well of a sterile, 24-well tissue culture plate; $0.5 \mathrm{ml}$ of the cell suspension was pipetted into each well. After $24 \mathrm{~h}$, non-adherent cells were washed off twice with phosphate-buffered saline (PBS). The protein kinase inhibitors were dissolved in dimethyl sulphoxide (DMSO) $0.25 \%$ at concentrations as follows: $516 \mu \mathrm{M}$ erbstatin, $306 \mu \mathrm{M}$ genistein, $25 \mu \mathrm{M}$ staurosporine. Each inhibitor solution $(0.5 \mathrm{ml})$ was added to three wells; three wells received the culture medium containing DMSO $0.25 \%$. After $60 \mathrm{~min}$, the coverslips were washed twice with PBS and $0.5 \mathrm{ml}$ of the medium was added to the wells. In another group, three of the wells were replenished with medium containing each inhibitor. M. leprae $\left(2 \times 10^{7} / 20 \mu \mathrm{l}\right)$ was added to all the wells. After incubation at $37^{\circ} \mathrm{C}$ for $2 \mathrm{~h}$, the coverslips were washed with PBS and stained by the Ziehl-Neelsen method for acid-fast bacteria. The coverslips were mounted on slides and photographed with a Zeiss Photomicroscope. The experiments were repeated three times, with similar results.

$b g / b g$ macrophages. The procedures followed were the same as for the BALB/c macrophages, except for the following changes. The number of macrophages in the medium was $2 \times 10^{6} / \mathrm{ml}$; concentrations of inhibitors used were: $250 \mu \mathrm{M}$ and $500 \mu \mathrm{M}$ erbstatin, $100 \mathrm{nM}$ and $200 \mathrm{nM}$ herbimycin, $100 \mu \mathrm{M}$ and $500 \mu \mathrm{M}$ genistein, $500 \mathrm{nM}$ and $5 \mu \mathrm{M}$ staurosporine. The $\mathrm{IC}_{50}$ values of the inhibitors vary widely and their effects are not always concentration-dependent [6]. There was no pre-incubation of the macrophages with the inhibitors, which were added to the reaction mixture. M. leprae $\left(1.8 \times 10^{7} / 0.5 \mathrm{ml}\right)$ was added to the wells and incubated for $4 \mathrm{~h}$ at $37^{\circ} \mathrm{C}$. The coverslips were washed twice with PBS and fixed in formaldehyde 10\% in ethanol. After staining by the Ziehl-Neelsen method, the number of acid-fast bacilli in 100 macrophages on each slide was counted. The results are expressed as the mean (SD) of three counts, from representative experiments.

\section{Results}

\section{$B A L B / c$ macrophages}

The control macrophages showed good internalisation of M. leprae (Fig. 1). Phagocytosis of the bacteria was suppressed in the macrophages exposed to staurosporine and erbstatin (Figs. 2 and 3). Genistein showed no effect, the bacteria being internalised as in the controls (Fig. 4). The macrophages exposed to staurosporine or erbstatin remained attached to the coverslips, indicating that they were still viable. Even after the inhibitors had been removed after pre-incubation with the cells, those cells treated with erbstatin or staurosporine did not phagocytose the bacteria. The same results were obtained whether the cells remained exposed to the inhibitory compounds or the inhibitors were washed off after pre-incubation.

\section{bg/bg macrophages}

Beige $(b g / b g)$ mice are mutants derived from the C57 parent strain and are considered to be deficient in natural killer (NK) cells. In the control macrophages, not exposed to the protein kinase inhibitors, 83(SD3)\% of the cells phagocytosed M. leprae (Table 1). Phagocytosis of the bacteria was suppressed by all the inhibitors at both the concentrations tested. Genistein, which had no effect on macrophages of $\mathrm{BALB} / \mathrm{c}$ mice, produced the greatest inhibition in the $b g / b g$ macrophages. The extreme susceptibility of these phagocytic cells from the genetically deficient $b g / b g$ mice to protein kinase inhibitors requires further study.

\section{Discussion}

Protein phosphorylase regulates a variety of cellular functions. The kinases phosphorylate specific amino acids in proteins; the enzyme phosphatase that dephosphorylates the protein returns the system to its original state. Phosphorylase and phosphatase are involved in

Fig. 1. Phagocytosis of $M$. leprae by BALB/c macrophages; magnification $\times 1500$.

Fig. 2. Staurosporine inhibition of phagocytosis of $M$. leprae; magnification $\times 1500$.

Fig. 3. Erbstatin inhibition of phagocytosis of $M$. leprae; magnification $\times 1500$.

Fig. 4. Phagocytosis of M. leprae by macrophages in the presence of genistein; magnification $\times 1500$. 


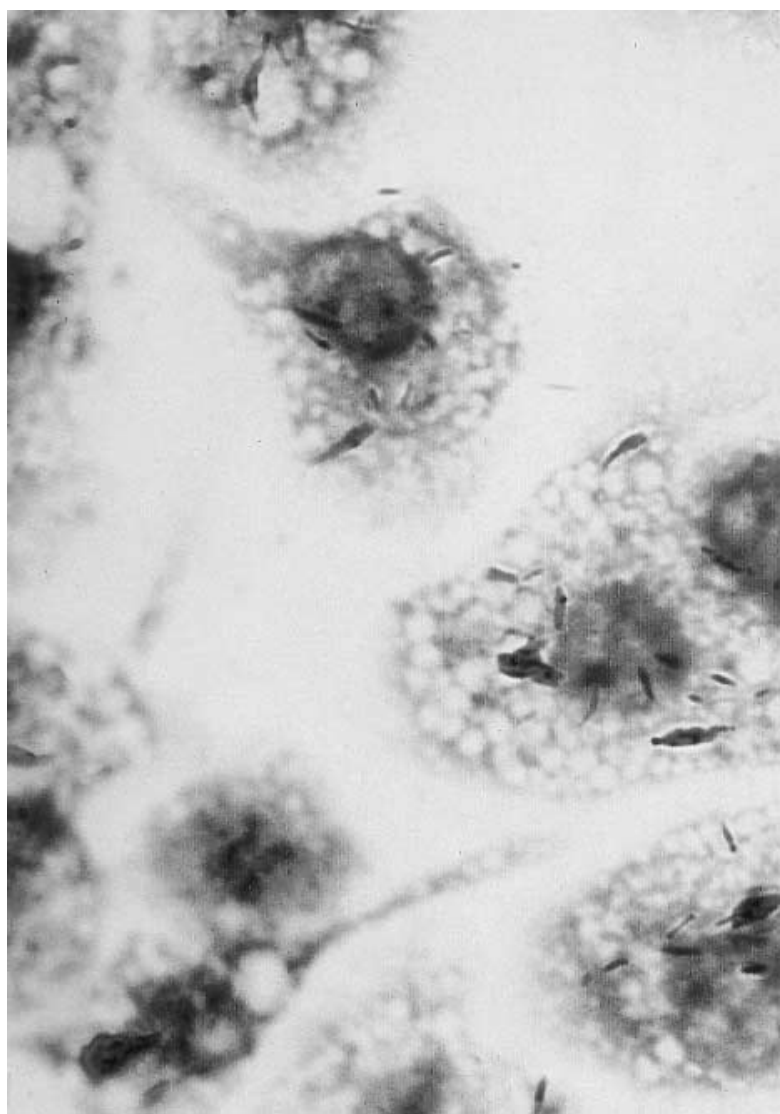

Fig. 1.

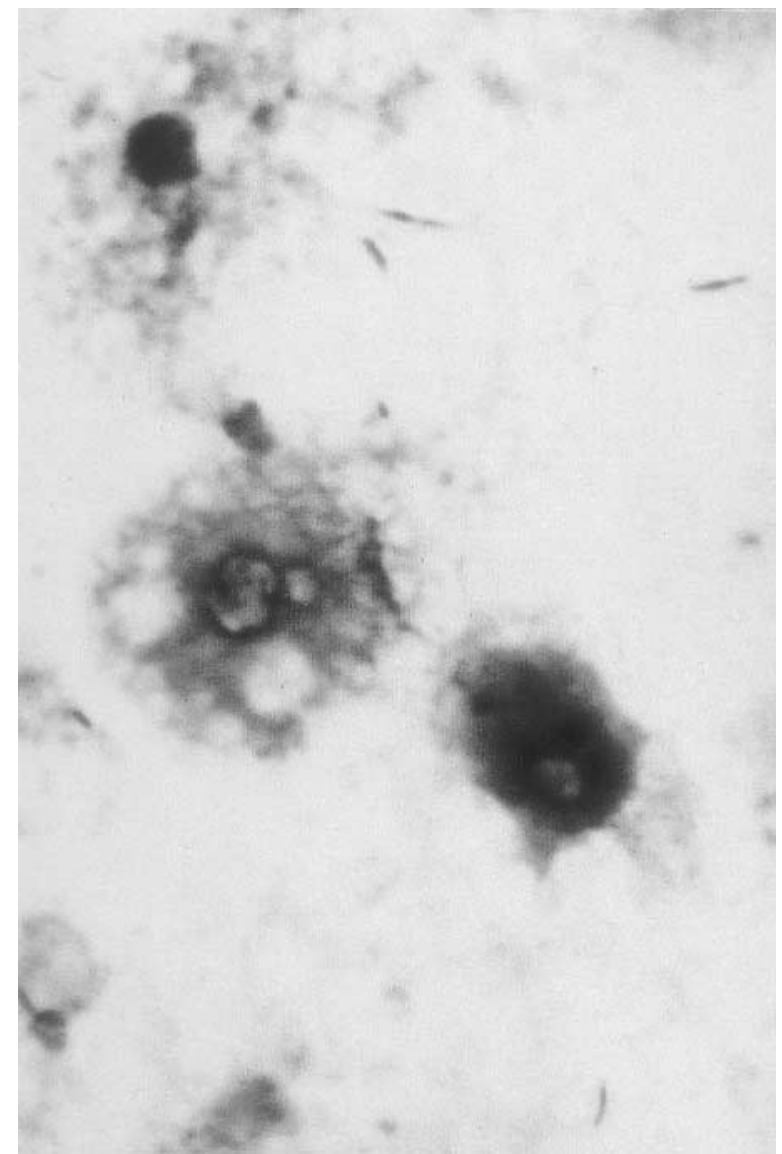

Fig. 3.

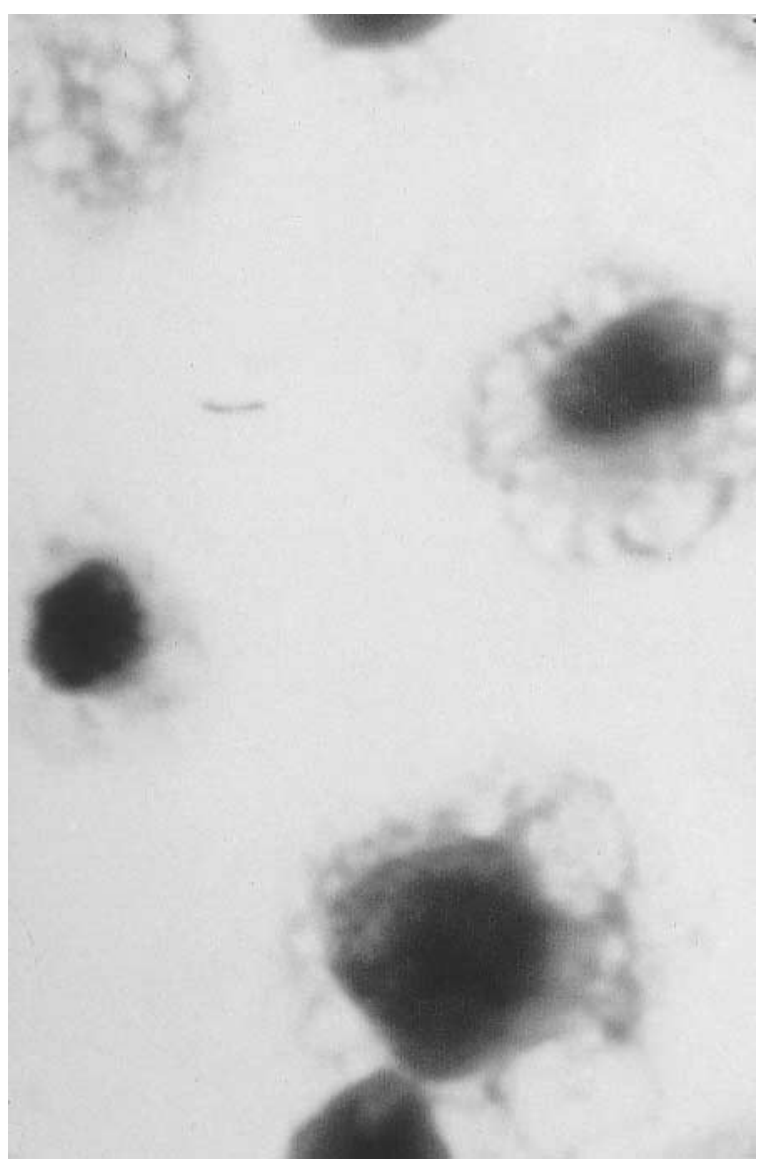

Fig. 2.

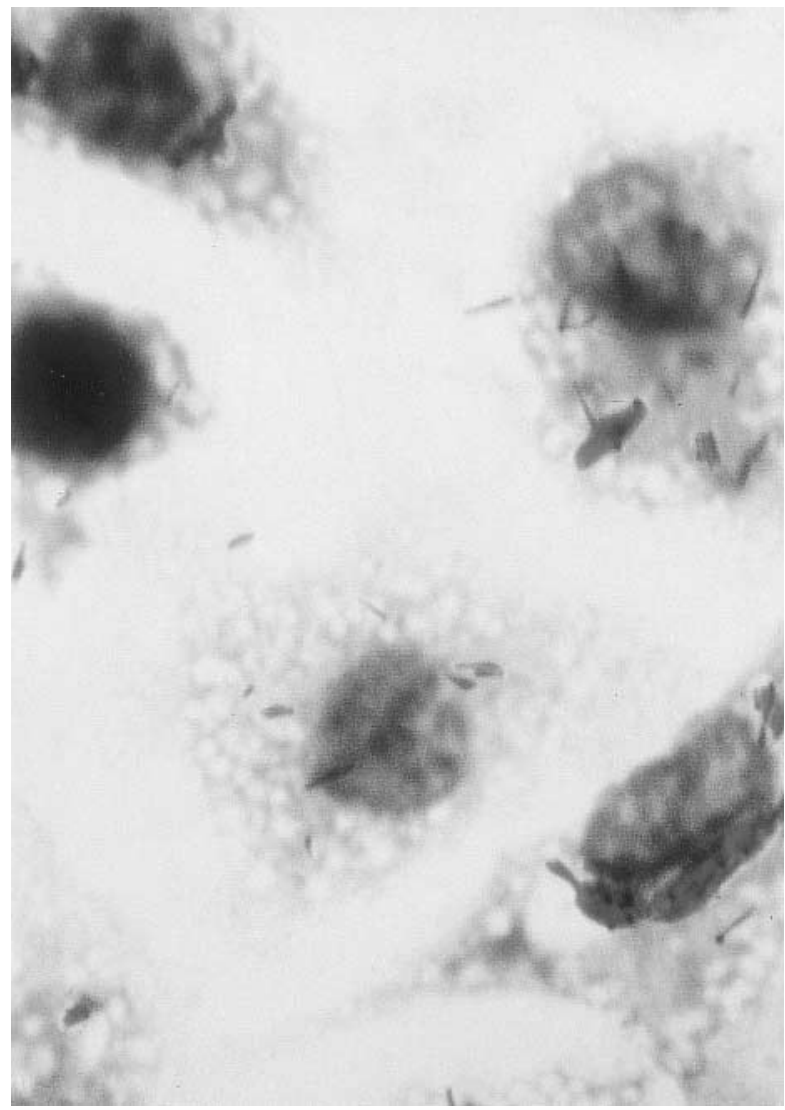

Fig. 4. 
Table 1. Effects of protein kinase inhibitors on the phagocytosis of $M$. leprae by macrophages of beige $(b g / b g)$ mice

\begin{tabular}{lcc}
\hline Inhibitors & $\begin{array}{c}\text { Concentration of } \\
\text { inhibitors }\end{array}$ & $\begin{array}{c}\text { Mean (SD) percent of cells } \\
\text { taking up M. leprae }\end{array}$ \\
\hline None & - & $83(3)$ \\
Erbstatin & $250 \mu \mathrm{M}$ & $8(2)$ \\
Herbimycin & $500 \mu \mathrm{M}$ & $5(2)$ \\
& $100 \mathrm{nM}$ & $7(3)$ \\
Genistein & $200 \mathrm{nM}$ & $13(2)$ \\
& $100 \mu \mathrm{M}$ & $5(1)$ \\
Staurosporine & $500 \mu \mathrm{M}$ & $2(1)$ \\
& $500 \mathrm{nM}$ & $20(10)$ \\
& $5 \mu \mathrm{M}$ & $10(4)$ \\
\hline
\end{tabular}

the most crucial reactions carried out by organisms. Protein kinases and phosphatases have been found not only in eukaryotes but also in a wide range of bacteria [3]. In Listeria monocytogenes which invades nonphagocytic cells, cell penetration by the bacteria is associated with host cell tyrosine phosphorylation [7]. Protein kinase has been shown to mediate phagocytosis of $M$. bovis BCG [8].

The mechanism of action may not be the same for the different protein kinase inhibitors. Many tyrosine kinase inhibitors are not very selective, acting on several tyrosine kinases. Staurosporine is a potent broad-range inhibitor of protein kinases [9]. In vitro, genistein is a competitive inhibitor of ATP in the kinase reaction, but it has no efficacy in vitro [10] and did not prevent uptake of $M$. leprae by $\mathrm{BALB} / \mathrm{c}$ macrophages in the present study. Erbstatin was reported to be competitive with both protein and ATP [11]. Herbimycin inhibits tyrosine kinase irreversibly [12].

Tyrosine phosphorylation was shown to be one of the signalling events mediating the uptake of $M$. tuberculosis by macrophages $[13,14]$. The results of the present study demonstrate that protein kinase is a factor that regulates phagocytosis of $M$. leprae by macrophages. Further investigation of the various types of protein kinases has not been pursued in this study. As mycobacteria such as M. tuberculosis and M. leprae multiply within the phagocytic cells of the host, blocking protein phosphorylase could be a rational drug target against infections caused by the bacilli [11].

We thank Mr J. P. Pasqua for harvesting the macrophages and $\mathrm{Mr}$ Gregory McCormick for preparing the figures.

\section{References}

1. Hunter T. Tyrosine phosphorylation: past, present and future. Biochem Soc Trans 1996; 24: 307-327.

2. Smith SC, Kennelly PJ, Potts M. Protein-tyrosine phosphorylation in the Archaea. J Bacteriol 1997; 179: 2418-2420.

3. Kennelly PJ, Potts M. Fancy meeting you here! A fresh look at "prokaryotic" protein phosphorylation. J Bacteriol 1996; 178: 4759-4764.

4. Kolibaba KS, Druker BJ. Protein tyrosine kinases and cancer. Biochim Biophys Acta 1997; 1333: F217-F248.

5. Thelen M, Wirthmueller U. Phospholipases and protein kinases during phagocyte activation. Curr Opin Immunol 1994; 6: 106-112.

6. Suzuki K, Azuma Y, Onoshi Y, Kizaki H, Ishimura Y. Biphasic effects of staurosporine on thymocyte apoptosis. Biochem $\mathrm{Mol}$ Biol 1995; 35: 1085-1092.

7. Velge P, Bottreau E, Kaeffer B, Yurdsev N, Pardon P, Van Langendonck N. Protein tyrosine kinase inhibitors block the entries of Listeria monocytogenes and Listeria ivanovii into epithelial cells. Microb Pathog 1994; 17: 37-50.

8. Buchwalow IB, Emoto M, Brich M, Kaufman SHE. Signal transduction and phagosome biogenesis in human macrophages during phagocytosis of Mycobacterium bovis BCG. Acta Histochem 1997; 99: 63-70.

9. Magae Y, Magae J. Effect of staurosporine on growth of hyphal morphology of Pleurotus ostreatus. J Gen Microbiol 1993; 139: 161-164

10. Schönherr E, Kinsella MG, Wight TN. Genistein selectively inhibits platelet-derived growth factor-stimulated versican biosynthesis in monkey arterial smooth muscle cells. Arch Biochem Biophys 1997; 339: 353-361.

11. Levitzki A, Gazit A. Tyrosine kinase inhibition: an approach to drug development. Science 1995; 267: 1782-1788.

12. Azuma Y, Onishi Y, Hirata C, Tanimoto Y, Yamada T, Kizaki H. Staurosporine-induced thymocyte apoptosis is inhibited by herbimycin A, a specific inhibitor of protein tyrosine kinase. Biochem Mol Biol Int 1995; 37: 635-643.

13. Kusner DJ, Hall CF, Schlesinger LS. Activation of phospholipase D is tightly coupled to the phagocytosis of Mycobacterium tuberculosis or opsonized zymosan by human macrophages. J Exp Med 1996; 184: 585-595.

14. Deretic V, Fratti RA. Mycobaterium tuberculosis phagosome. Mol Microbiol 1999; 31: 1603-1609. 